М. С. Силантьева // Вестник Пермского университета. Российская и зарубежная філология. - 2010. - Вып. 6(12). - С. 71-75. - Режим доступа к журн.: http://www.rfp.psu.ru/archive/6.2010/kushnina_silantjeva.pdf 7. Лозова В. I. Педагогічні цінності сучасної освіти / Валентина Іванівна Лозова // Педагогічна і психологічна наука в Україні : зб. наук. пр. до 15-річчя АПН України : у 5 т. - К. : Пед. думка, 2007. - Т. 1. Теорія та історична педагогіка. - С. 68-79. 8. Лутай В. С. Синергетична парадигма як філософсько-методологічна основа формування світоглядів XXI століття / В. С. Лутай // 3б. наук. праць. - Вип. 3; за заг. ред. В. А. Андрущенка. - К. : Знання, 2000. - 244 с. 9. Плехов А. Н. Психологические условия развития вторичной языковой личности преподавателя-лингвиста : автореф. дис. на соискание ученой степени канд. психол. наук / А. Н. Плехов. - Н.Новгород, 2007. - 23 с. 10. Семеног О. Академічна лекція як професійний комунікативний феномен / О. Семеног // Естетика і етика педагогічної дії: зб. наук. пр./ Інститут педагогічної освіти i освіти дорослих НАПН України; Полтавський національний педагогічний університет імені В. Г. Короленка. - Вип. 1. К. ; Полтава : ПНПУ ім. В. Г. Короленка, 2011. - С. 113-121.

УДК $37.025+159.942$

Ірина Дишлева

\title{
РОЗРОБЛЕННЯ ПРОБЛЕМИ ЗБЕРЕЖЕННЯ І ЗМІЦНЕННЯ ЗДОРОВ'Я УЧНІВ В УМОВАХ ЗАГАЛЬНООСВІТНЬОГО НАВЧАЛЬНОГО ЗАКЛАДУ
}

Дишлева I. М. Розроблення проблеми збереження і зміцнення здоров'я учнів в умовах загальноосвітнього навчального закладу.

У статті розкрито стан розроблення проблеми впровадження здоров'язбережувальних технологій у навчально-виховний процес загальноосвітнього навчального закладу. Здійснено грунтовний аналіз нормативно-правової бази щодо організаційно-методичного забезпечення у процесі застосування здоров' язбережувальних технологій.

Ключові слова: здоров'я, здоров'язбережувальні технології, загальноосвітній заклад, учні основної школи.

Дышлева И. Н. Разработка проблемы сбережения и укрепления здоровья учеников в условиях общеобразовательного учебного заведения.

В статье раскрыто состояние разработки проблемы внедрения здоровьесберегающих технологий в учебный процесс общеобразовательного заведения. Произведен глубокий анализ нормативно-правовой базы касательно организационнометодического обеспечения в процессе применения здоровьесберегающих технологий.

Ключевые слова: здоровье, здоровьесберегающие технологии, общеобразовательное заведение, ученики основной школы.

Dyshleva I. N. Development problems and strengthening health savings in terms of general education students academic institutions.

The article reveals the state of development problems of implementation of healthtechnologies in the educational process in secondary institution. Made a deep analysis of the legal framework regarding organizational methods in the application of health- technology.

Key words : Health, Health- technology, educational institution, primary school pupils.

Теоретичний і практичний досвід у галузі здоров'язбереження дітей переконує в доцільності здійснення грунтовного аналізу основ здоров'язбереження дітей за такими 
напрямами: соціально-медичний і психолого-педагогічний, що дозволяє виокремити чинники ризику в умовах загальноосвітнього навчального закладу: неефективна педагогічна тактика; інтенсифікація навчального процесу; вибір методик і педагогічних технологій, що не відповідають віковим та індивідуальним особливостям розвитку учнів; недотримання гігієнічних вимог щодо здійснення навчально-виховного процесу; низький рівень компетентності педагогів 3 питань здоров'язбереження учнівського контингенту; послаблення медичного контролю в школі; недостатня обізнаність батьків про засоби і методи збереження та зміцнення дитячого здоров'я; епізодичне, фрагментарне застосування в навчанні учнів елементів здоров'язбережувальних технологій; незначна кількість практичних напрацювань із проблеми впровадження здоров’ язбережувальних технологій у навчально-виховний процес.

Проблема підготовки вчителів до здоров'язбереження учнів має відображення в працях класиків педагогіки, зокрема Я. А. Коменського, Г. Сковороди, К. Ушинського, С. Русової, Г. Ващенка, В. Сухомлинського, А. Макаренка та ін. Це підтверджує актуальність означеної проблеми в минулому, але зауважимо, що особливої гостроти вона набула на сучасному етапі розвитку шкільної освіти. Дослідженню теоретичних і прикладних аспектів проблеми здоров'язбереження молодого покоління приділяли увагу вітчизняні та зарубіжні науковці, зокрема Г. Апанасенко, Л. Горяна, О. Дубогай, Л. Попова, С. Лапаєнко та ін. Сутність валеологічної культури учнів за сучасних умов навчання розкрили Т. Бойченко, О. Бондаренко, Л. Ващенко, М. Гончаренко, В. Горащук, В. Грибань, С. Кондратюк та ін. Соціальні проблеми здоров'я дітей i підлітків проаналізували Л. Бойко, Є. Неведомська, Ю. Науменко та ін. Головні чинники формування здоров'язбережувального освітнього середовища в школі визначили О. Ващенко, В. Звєкова, О. Клестова, К. Оглоблін та ін.

Узагальнюючи теоретичний і практичний доробок у галузі здоров'язбереження учнів, слід зазначити, що недостатньо розробленими залишаються питання організації здоров'язбережувальної діяльності вчителів під час навчання природничих предметів, що супроводжується загостренням суперечностей між: соціально зумовленою потребою впровадження здоров'язбережувальних технологій і недостатнім рівнем підготовки педагогічних кадрів до здоров'язбережувальної діяльності; наявним рівнем розробленості теоретичних основ здоров'язбережувальних технологій у наукових дослідженнях та їх недостатнім рівнем практичного впровадження в навчальновиховний процес школи; науково обгрунтованою доцільністю здоров'язбереження учнів і недостатнім рівнем підготовки вчителів загальноосвітнього навчального закладу до застосування здоров' язбережувальних технологій.

Становлення і розбудова України як суверенної держави визначає нові орієнтири в галузі освіти, що зумовлює модернізацію педагогічного процесу в загальноосвітніх навчальних закладах різного типу, викликає потребу розвитку інноваційної діяльності вчителів, спрямовуючи їх увагу на виконання соціального замовлення - виховання здорової, гармонійно розвиненої особистості учня. У статті 3 Конституції України задекларовано, що «людина, іiі життя і здоров'я, честь і гідність, недоторканість і безпека визнаються в Україні найвищою соціальною цінністю» [3, с. 2].

Модернізаційні процеси шкільної освіти визначають завдання збереження i зміцнення здоров'я молодого покоління, що вимагає розроблення та впровадження нормативно-правових основ діяльності загальноосвітніх навчальних закладів задля ефективного здійснення здоров'язбереження учнів.

Mema cmammi- розкрити стан розроблення проблеми впровадження здоров'язбережувальних технологій у навчально-виховний процес загальноосвітнього навчального закладу. 
У Національній доктрині розвитку освіти зазначено, що шкільна освіта повинна бути зорієнтована на «виховання людини в дусі відповідального ставлення до власного здоров'я і здоров'я оточуючих як до найвищої індивідуальної і суспільної цінності» [7, c. 5]. Отже, ефективне впровадження здоров'язбережувальних технологій у процесі навчання природничих предметів уможливлене завдяки розвитку валеологічної освіти, а також оптимізації навчально-виховного процесу і формуванню екологічно сприятливого життєвого середовища.

Цілком очевидною $є$ закономірність, що ефективність розв'язання проблеми здоров'язбереження молодого покоління значною мірою залежить від законодавчої підтримки 3 боку державної політики України. Зокрема, у змісті Міжгалузевої комплексної програми «Здоров'я нації» на 2002-2011 роки, прийнятої Постановою Кабінету Міністрів України 10 січня 2002 року з метою «поліпшення демографічної ситуації, збереження і зміцнення здоров'я населення» [6], акцентовано увагу на вихованні культури здоров'я учнів, оскільки діти і молодь $є$ одним із пріоритетів політики держави. Від рівня їх здоров'я великою мірою залежить формування трудового та інтелектуального потенціалу України» $[6$, с. 9]. Окреслений факт $\epsilon$ вагомим поштовхом до розроблення і впровадження методичного супроводу одного 3 пріоритетних напрямів шкільної освіти - здоров'язбереження дітей і підлітків.

Нині вагомості набуває здійснення профілактично-просвітницької роботи в загальноосвітніх навчальних закладах, що зорієнтована на недопущення поширення негативних явищ серед учнівської молоді (пияцтва, наркоманії, розпусти тощо), що актуалізує окреслене питання у процесі вивчення природничих дисциплін у загальноосвітньому навчальному закладі.

Обгрунтовуючи нагальність розроблення методичних рекомендацій щодо підвищення рівня організації санітарно-гігієнічної просвіти, В. Бобрицька висловлює думку про те, що донині переважає притаманний гігієнічній пропаганді просвітницький дидактизм, доведення до слухачів і читачів елементарних, загальновідомих, почасти констатувальних істин, що не сприяє формуванню моделі поведінки, яка б забезпечувала збереження здоров'я.

У Положеннях Державної національної програми «Освіта» (Україна XXI століття) [2] зазначається, що одним із стратегічних завдань $є$ «органічне поєднання навчання і виховання 3 метою забезпечення розумового, морального, художньоестетичного, правового, патріотичного, екологічного, трудового та фізичного розвитку дитини, формування здорового способу життя» [2, с. 5]. Результативність виконання зазначених у ній стратегічних завдань модернізації шкільної освіти буде ефективною за умов забезпечення оптимальних матеріально-технічних, санітарно-гігієнічних, організаційно-педагогічних і науково-методичних умов у загальноосвітній школі, що уможливить організацію діяльності загальноосвітніх навчальних закладів на високому рівні і сприятиме ефективному застосуванню вчителем здоров'язбережувальних технологій.

Окреслення перспективи розвитку здоров'язбережувального аспекту процесу викладання природничих предметів вимагає врахування відповідної сукупності умов, необхідних для формування здоров'язбережувального внутрішньошкільного середовища, сприятливого для розвитку пізнавальної, емоційно-вольової та потребнісно-мотиваційної сфер учнів основної школи.

Узагальнення вище викладеного дозволяє зробити висновок, що держава більшою мірою приділяла увагу розробленню нормативно-правової бази з проблеми збереження і зміцнення здоров'я учнів упродовж першого десятиліття існування суверенної України. 
Соціальна актуальність проблеми здоров'язбереження учнів доводиться низкою нормативно-правових актів, розроблених задля оптимізації здоров'я молодого покоління, зокрема: Укази Президента України: № 478/2009 від 23 червня 2009 р. «Про деякі заходи щодо вдосконалення системи фізичного виховання дітей і молоді у навчальних закладах і розвитку дитячо-юнацького спорту в Україні», № 657/2010 від 1 червня 2010 р. «Про літнє оздоровлення та відпочинок дітей у 2010 році», № 1163/2011 від 16 грудня 2011 р. «Про питання щодо забезпечення реалізації прав дітей в Україні»; Постанови Верховної Ради: № 536-V від 9 січня 2007 року «Про стан і перспективи розвитку загальної середньої освіти в Україні», № 2441-VI від 6 липня 2010 «Про рекомендації парламентських слухань на тему: «Запровадження 12-річної загальної середньої освіти в Україні: проблеми та шляхи їх подолання», № 2992-VI від 3 лютого 2011 р. «Про рекомендації парламентських слухань про становище молоді в Україні на тему: «Молодь за здоровий спосіб життя», № 3351-VI від 12 травня 2011 р. «Про рекомендації парламентських слухань 3 питань оздоровлення та відпочинку дітей і молоді»; Постанови Кабінету Міністрів: № 348 від 11 березня 1999 р. «Про затвердження комплексного плану заходів щодо розвитку загальної середньої освіти в 1999-2012 роках», № 422 від 28 квітня 2009 р. «Про затвердження Типового положення про дитячий заклад оздоровлення та відпочинку».

Отже, державна політика значною мірою сприяє розвитку шкільної освіти, надаючи допомогу в розробленні ефективних підходів до розв'язання проблеми здоров'язбереження учнів. Концепція загальної середньої освіти (12-річна школа), що містить рекомендації стосовно обов'язкового запровадження навчального предмета «Основи здоров'я» [4], орієнтованого на утвердження засад здорового способу життя учнів.

У Концепції неперервної валеологічної освіти в Україні [5] констатується спрямованість на усунення розбіжностей між знаннями, набутими в школі (у процесі навчання природничих предметів) і реальним станом справ у сучасному суспільстві; акцентовано увагу на меті, принципах, змісті і структурі валеологічної освіти, покликані забезпечити розвиток здорової особистості учня, здатної до самовдосконалення.

Авторами Концепції неперервної валеологічної освіти в Україні (Т. Бойченко,

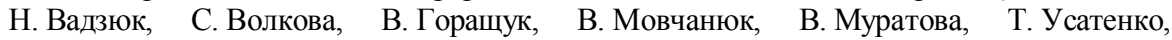
А. Царенко, М. Шабатура) виокремлено такі валеологічні принципи:

1. Науковість і доступність змісту валеологічної освіти, що означає встановлення взаємозв'язку між науковими знаннями про здоров'я і народними традиціями, а також відповідність потребам усіх ланок педагогічного процесу.

2. Системність у розгляді проблем здоров'я, зорієнтоване на послідовне, системне опанування основ валеології задля збереження й зміцнення здоров'я кожного окремого учня та всього учнівського колективу.

3. Гуманізація - сприйняття людини в гармонійному поєднанні 3 довкіллям та спрямування на усвідомлення вагомості людиноцентристського принципу.

4. Інтегративність - охоплення здоров'язбережувальною діяльністю всіх підструктур середнього загальноосвітнього навчального закладу [138, с. 8-9].

Визначені принципи вказують на пріоритет здоров'я людини в освітній галузі. Вони зорієнтовані на формування валеологічного світогляду, ціннісного ставлення до здоров'я як однієї з головних умов самореалізації особистості внаслідок розкриття іiі творчого й фізичного потенціалу.

За даними Міністерства охорони здоров’я України збільшився відсоток учнівської молоді, яка страждає на гіпертонію та неврози. До найпоширеніших хвороб учнів варто віднести захворювання очей, опорно-рухового апарату, травної, ендокринної системи, а 
також порушення психіки, патологія репродуктивної системи та наявність новоутворень. Доказом цьому слугують такі дані: починаючи від першого до дев'ятого класу частота порушень постави зростає у 1,5 рази; зниження гостроти зору - у 1,5 рази; патологія травної системи - у 1,4 рази, а ендокринної- у 2,6 рази. Лише $7 \%$ учнів мають задовільний стан здоров'я. Серед учнів середніх загальноосвітніх навчальних закладів простежується чітка тенденція до погіршення здоров'я, яка супроводжується проявами астенізації, послаблення м'язової сили, зниженням окружності грудної клітки та життєвої ємкості легень [8].

Зауважимо, що не слід залишати без уваги i соціально детерміновані захворювання, а саме: тютюнопаління, вживання алкоголю, наркотиків, ВІЛ/СНІД, туберкульоз, хвороби, що передаються статевим шляхом. Зокрема, за даними опитування Держкомстату, у 2002 році рівень тютюнопаління серед представників окресленої вікової категорії становив 22,9\% , а в 2012 році досяг 25,4 \%. За останнє десятиліття до 5,4 тисяч зросла кількість наркозалежних серед неповнолітніх. Змушує замислитися невтішна статистика щодо поширення епідемії ВІЛ/СНІД. Відомо, що наприкінці минулого століття у світі нараховувалося 58 мільйонів ВІЛ-інфікованих, 3 яких 10 мільйонів дітей.

Отже, постає проблема розроблення ефективних напрямів збереження і зміцнення здоров'я дітей i підлітків, розв'язання проблеми ефективного упровадження здоров'язбережувальних технологій у процесі навчання природничих предметів в основній школі уможливлене якісними змінами в системі загальної середньої освіти та налагодженні ефективних соціально-економічних відносин у суспільстві загалом.

Здійснений аналіз нормативно-правової бази доводить доцільність нагального розв'язання проблемних аспектів здоров'язбереження учнів основної школи в процесі навчання природничих предметів.

\section{Література}

1. Бобрицька В. I. Теоретичні і методичні основи формування здорового способу життя у майбутніх учителів у процесі вивчення природничих наук : дис. ... доктора пед. наук : 13.00.04 / Валентина Іванівна Бобрицька. - К., 2006. - 489 с. 2. Державна національна програма «Освіта» (Україна XXI століття) : Затв. Кабінетом Міністрів України від 3 листопада 1993 р. № 896. - К. : Райдуга, 1994. - 62 с. 3. Конституція України, прийнята на п'ятій сесії ВРУ 28 червня 1996 р. - К. : Преса України, 1997. 80 с. 4. Концепція загальної середньої освіти (12-річна школа) // Директор школи. 2002. - № 1. - С. 5-15. 5. Концепція неперервної валеологічної освіти в Україні// Шкільний курс «Валеологія» : зб. матеріалів. - К. : Освіта, 1994. - 94 с. 6. Методологічні та методичні підходи до реалізації Міжгалузевої комплексної програми «Здоров’я нації». 3 досвіду виконання програми та координації цієї роботи : методичні рекомендації / за ред. В. М. Пономаренка. - К., 2007. - 35 с. 7. Національна доктрина розвитку освіти / Затверджено Указом Президента України від 17.04.2002. № 347/2002 // Освіта України. - 23 квітня 2002 р. - № 33. - С. 4-6. 8. Стан здоров’я учнів загальноосвітніх навчальних закладів обговорювали на засіданні колегії СЕС України [Електронний ресурс]. - Режим доступу : http:/www.moz.gov.ua/ua/ main/press/? $\operatorname{doc} \mathrm{ID}=11579$. - Заголовок з екрана. 